\author{
Marie-Noelle CRÉPY ${ }^{1,2}$ \\ ${ }^{1}$ Department of Occupational Diseases \\ Paris University Hospital, Centre COCHIN, \\ AP-HP \\ 27 rue du Fb St Jacques 75014 Paris, France \\ ${ }^{2}$ Rehabilitation - Evaluation - Reintegration \\ (RER) \\ Department of Occupational Health and \\ Reintegration \\ 104 Boulevard Raymond Poincaré \\ 92380 Garches
}

Reprints: M.-N. Crepy

$<$ marie-noelle.crepy@orange.fr>

Article accepted on 01/2/2015

\section{Skin diseases in musicians}

Instrumental musicians are a risk group for skin diseases. A systematic review was performed on Pubmed database and in the musical literature. Most publications on dermatoses in musicians are case reports. The exact prevalence of skin diseases in musicians is unknown but high rates have been reported. The most at-risk musicians are percussionists, string and wind instrumentalists. Repeated physical trauma is a frequent cause of skin conditions in musicians (callosities, fiddler's neck syndrome...). The allergens most often reported in musicians' allergic contact dermatitis are metals (nickel, dichromate), exotic woods and cane reed components, colophony and propolis. The key preventive measures are early management of the skin disease, specific tests and avoidance of the causative allergens, together with better adjustment of playing techniques to reduce trauma.

Key words: allergens, dermatitis, diagnosis, irritants, musicians, occupational diseases
$\mathrm{P}$ rofessional musicians are a particularly at-risk group for the development of musculoskeletal disorders, neurological disorders (hand dystonia...) and hearing loss. The exact prevalence of skin diseases in musicians is unknown but high rates - up to $50 \%$ - have been reported [1]. The most at-risk musicians are percussionists, string and wind instrumentalists. Stress is a particularly frequent aggravating factor in this population. The consequences of skin diseases on the careers of professional artists can be tragic due to the performance requirements at such a high-level.

\section{Classification of musical instruments}

There are several types of classification of musical instruments. They are traditionally divided into four categories, depending on the primary vibrating element producing the sound (table 1). Cordophones, or string instruments, create sound by way of a vibrating string or strings. In aerophones, or wind instruments, the vibrating element is the body of air created by the breath of the instrumentalist (clarinet...), bellows (organ...) or an air reservoir (bagpipes). In idiophones, the vibrating element is the instrument as a whole (xylophone...) whereas in membranophones the vibrating element is a stretched membrane (drum...).

\section{Composition of instruments}

\section{String instruments (cordophones)}

There is a wide range of woods used in the making of musical instruments and it is impossible to provide an exhaustive list of them due to different traditions, depending on the country and era. In the $19^{\text {th }}$ century, processes were standardised and different "standard" types of woods were used, depending on the instruments [3]. Nowadays, international agreements for the protection of endangered species of fauna and flora (CITES: Convention on International Trade in Endangered Species of Wild Fauna and Flora, http://www.cites.org) provide more stringent regulations of certain woods such as Brazilian rosewood (Dalbergia nigra), Pernambuco wood (Caesalpinia echinata, Caesalpiniaceae, Leg.), cocobolo (Dalbergia retusa Hemsl), ebony (Diospyros genus)... One of the consequences of the restriction of the supply of endangered wood species is a greater diversification of the woods used to make instruments and the development of composite materials.

The soundboards of string instruments are usually made of resinous softwoods, particularly of the genus Picea, including Picea abies, which has a steady growth. The favourite woods are those with high elasticity moduli and low absorption coefficients [3]. As regards guitars, Pacific red cedar (Thuja plicata) is widely used, as it has a warmer tone than spruce [3]. The body of the instrument (back wood) is made of harder wood, usually curly maple in the case of violins. The classic back wood of guitars is Rio rosewood but it tends to be replaced by Indian rosewood (Dalbergia latifolia). Cypress is used for flamenco guitars.

The bow is made of a wood stick (usually Pernambuco Caesalpinia echinata, Caesalpiniaceae, Leg.) and of strands of horsehair. Other woods can be used, such as snakewood (Brosimum guianense, Moraceae) for baroque bows, as it is denser than Pernambuco. The bow frog is made of ebony and metal alloy, sometimes decorated with mother-of-pearl and, in the past, with tortoiseshell. The fingerboard is often made of ebony (Diospyros genus) or of different types of rosewood or of deal (maple....). Chin rests are either made of ebony, Dalbergia or boxwood. Boxwood is also widely used for bagpipes. 
Table 1. Classification of musical instruments into 4 categories depending on the primary vibrating element producing the sound $[2]$.

\begin{tabular}{|lll|}
\hline Categories & Characteristics & Examples \\
\hline $\begin{array}{l}\text { String instruments } \\
\text { (cordophones) }\end{array}$ & $\begin{array}{ll}\text { Bowed strings } \\
\text { Plucked strings }\end{array}$ & Violin, viola, cello, double bass, viol... \\
\hline $\begin{array}{l}\text { Wind instruments } \\
\text { (aerophones) }\end{array}$ & Voice & Harpsichord, guitar, harp, mandolin, lute, lyre... \\
\cline { 2 - 3 } & Boodwind & Piano, dulcimer... \\
\hline Krass & Keyboard & Bugle, horn, cornet, trombone, trumpet, tuba... \\
\hline Idiophones & Keyboard percussions & Organ, accordion, harmonium... \\
\hline Membranophones & Others & Xylophone, marimbas... \\
\hline
\end{tabular}

The materials used for the strings may vary depending on the type of instrument. Depending on the type of guitar (classical, electric, acoustic), they can be in nylon, catgut, metal (steel, nickel-plated steel, nickel, bronze, silverplated bronze). Similarly, violin strings can be made of steel, catgut or synthetic materials wrapped with aluminium.

\section{Wood instruments (aerophones)}

\section{Woodwind instruments}

Today's clarinets and oboes are made of granadilla or Mozambique ebony (Dalbergia Melanoxylon Guill. \& Perr), a very heavy and stable wood [3]. Boxwood was formerly used in ancient woodwind instruments such as clarinets, baroque oboes and recorders. Other species of trees can also be found such as fruit trees (pear tree) maple (German bassoon. ..), Brazilian rosewood (Dalbergia nigra for the French bassoon). New ranges of wind instruments are made of composite materials.

Some woodwind instruments have reeds that can be either a single reed (clarinet, saxophone) or a double reed (oboe and bassoon). The single reed is attached to the mouthpiece by the ligature. As the player blows air into the instrument, the reed (a thin strip of cane) flaps against the mouthpiece, which produces the sound. The oboe and bassoon have a double reed made of two thin strips of cane attached to an Sshaped tube. The reeds of woodwind instruments are often made of cane (Arundo donax), also called Provence cane, a plant belonging to the family gramineae (or poaceae). Some reeds can be made of plastic (such as polypropylene) or resin but their use remains marginal. The mouthpiece of a woodwind instrument is traditionally made of ebonite. The keywork of a clarinet or oboe is made of nickel silver, an alloy of brass, zinc and nickel. It is usually silver-plated but can also be nickel-plated.

Student-level flutes are usually made of silver-plated nickel silver whereas professional flutes are made of silver or gold alloy, which produces a better sound.

\section{Brass instruments}

The materials used to make brass instruments are, depending on the parts, brass (an alloy made of copper and zinc; the proportions vary depending on the instrument manufacturers) and nickel silver. Brass instruments are either in raw brass or coated with lacquer (cellulose lacquer or epoxy lacquer) or silver-plated, depending on the desired tone. The mouthpiece of brass instruments is usually made of silver-plated brass. In case of allergy, the mouthpiece can be gold-plated or made of plastic or boxwood. Slide trombones can have parts made of chrome-plated nickel silver to slide more easily.

\section{Percussion instruments (idiophones and membranophones)}

For xylophones and keyboard percussions, tropical woods are mainly used for their sound quality. Such woods only slightly absorb vibrations. Temperate woods are rarely used as they absorb the sound too much. Upscale percussion instruments designed for western music have keys made of rosewood, mainly Honduran rosewood. But other woods are or have been used, such as Brazilian rosewood (Dalbergia nigra) and broad-leaved woods such as birch, beech and maple [3]. Membranophones have skins (either animal or synthetic skin) stretched over shells made of wood, metal (brass, steel...) or composite materials.

\section{Epidemiology}

In a questionnaire study, Gambichler et al. [4] assessed the frequency of skin disorders in musicians from 19 German universities of music and performing arts. The questionnaire included questions on age, gender, the instrument(s) they played, the number of years of practice, the weekly duration of practice, the type of skin disease and whether it affected the way they play. Of the 3,120 questionnaires mailed, 412 were completed and returned (13.2\%). 89 musicians of $412(21.6 \%)$ reported skin symptoms induced by their instruments: callosities for over half of them $(52 / 89$; $58.4 \%)$, contact dermatitis $(17 / 89 ; 19.1 \%)$, fiddler's neck $(17 / 89 ; 19.1 \%)$ and erosions $(3 / 89 ; 3.4 \%)$. String, plucking and brass instrumentalists most frequently reported callosities. Among 117 violinists and violists, 17 suffered from fiddler's neck. The allergens inducing allergic contact dermatitis (relevant and positive patch tests) were nickel (11 cases), colophony (1 case) and lanolin (1 case). The skin disease moderately affected music making in about a quarter 
of cases and the effect was severe in about $2 \%$ of cases. The occurrence of skin conditions was significantly associated with total duration of weekly music making.

Baccouche et al. carried out a multicentre, prospective, cross-sectional study over a one-year period (2003-2004) in all of the music students registered in the 4 main musical institutes of Tunisia. 594 were included, 126 of whom were also professional musicians. The study included epidemiological and clinical data but patch test results are not mentioned. Instruments were divided into 3 categories: string instruments, wind instruments and percussions. A skin disease was diagnosed by physical examination in nearly half of the cases. Callosities represented over $60 \%$ of skin conditions and were reported mainly in percussionists and string instrumentalists. More occasionally, pigmentation abnormalities in areas of friction between the skin and the instrument (about 14\%), irritant contact dermatitis (about 10\%) and less frequently acne, erythema, friction bulla, nail dystrophy, cicatricial alopecia and unspecified contact dermatitis were reported.

Onder [5] carried out a questionnaire study in 97 orchestra players, nearly $50 \%$ of them had skin conditions. Most of these conditions were fiddler's neck ( 9 cases) and hyperhidrosis (8 cases). Allergic contact dermatitis was diagnosed in 4 patients with a positive patch test result to colophony in a violinist who had had hand dermatitis for a year and positive patch test results to nickel in 2 violinists and one clarinettist.

\section{Etiologies}

\section{Irritant contact dermatitis}

Repeated physical trauma is a frequent cause of skin conditions in musicians. It mainly occurs in the early weeks of practice or during periods of intensive practice. Such trauma can induce callosities, bulla, very painful skin erosions and haemorrhages. The location of callosities and traumatic lesions depends on the instrument played; left thumb in cellists, backs of the $2^{\text {nd }}$ and $3^{\text {rd }}$ fingers of the left hand on the proximal interphalangeal joints in violinists, the joint of the left ring finger in drummers, the median part of the upper lip in wind and brass instrumentalists, the chin in flautists and circumscribed atrophy of the upper lip in horn players. Repeated contact with the strings (viola, harp...) can lead to nail dystrophy and paronychia $[6,7]$. One of the most common types of trauma-induced dermatitis in musicians is the fiddler's neck syndrome, induced by violins and violas. Some authors call it acne mechanica [8]. There is a much greater variety of clinical aspects in fiddler's neck syndrome than in the usual irritant contact dermatitis. The lesions can be localised plaques of erythema, sometimes pigmented or lichenified, or acne-like lesions including papules, pustules and even cysts [8-11]. These lesions are located below the jaw where the instrument is in contact with the skin. Histopathology reveals acanthosis, histiocytic infiltrates with the presence of foreign body granuloma and follicular cysts. Etiology is still partly unknown and could be due to several factors, such as prolonged pressure, friction, shearing stress, occlusion and sweating [12]. Similar lesions are reported with other instruments, on the knees and sternal region in cellists and on the nipples in guitarists [7].The cleaning of instruments with solvents can also induce irritant contact dermatitis.

\section{Allergens inducing allergic contact dermatitis (ACD)}

\section{Nickel}

Nickel is a frequent allergen in musicians. It is found in the following instruments: string instruments (violins, cellos and guitars), wind instruments (flutes) and brass instruments (trumpets). Nickel silver is a nickel-based alloy widely used in the manufacturing of brass instruments. As a general rule, there is no direct relationship between the amount of nickel in the alloy and the sensitising potency. The risk of sensitisation depends on the number of free nickel ions in the surroundings. For a nickel-containing alloy, the main factor is its resistance to corrosion - particularly from sweat - and the formation rate of free nickel ions and the nickel skin concentration (amount of nickel per skin unit area present in the epidermis following nickel exposure) [13].

Several cases of nickel-induced ACD from the metal fixtures and brackets of violins have been reported [9, 14, 15]. Jue et al. [14] reported patches of dermatitis on the neck of a violist (Fiddler's neck syndrome) from the nickel contained in the metal fixtures of a viola. Patch testing gave positive results for nickel sulphate of the standard series and the metallic part of the viola in contact with the skin was positive on the dimethylglyoxime test. The lesions disappeared after the metal fixture was replaced by a nickelfree one (demethylgloxime test was negative). Caero et al. report a similar case in a young violin player [9]. Cutaneous examination revealed a pigmented plaque on the left submandibular neck corresponding to the friction of the chin rest on the neck and another pruritic, erythematous and squamous plaque on the left supraclavicular neck resulting from contact of the brackets holding the chin rest. The patient reported a history of allergic reaction to costume jewellery. No patch test results were mentioned. The replacement of the chin rest by a hypoallergenic Wittner ${ }^{\circledR}$ composite 4/4 side mount chin rest with no metal brackets, as well as a bandage placed on the friction area, lead to healing of the lesion.

Machàckovà et al. reported a vesicular dermatitis on the second and third fingers of the right hand of 6 months duration in a professional cellist. Patch testing was positive for nickel sulphate and as well as the dimethylglyoxime test for the metallic part of the bow in contact with the affected fingers [16].

Several cases of nickel-induced ACD from guitar strings have been reported [17-19]. Marshman and Kennedy reported dermatitis of the fingers of the right hand in a guitar player [17]. Patch testing for nickel in the European standard series and for a short length of guitar-string gave positive results. Changing to 24-carat-gold strings led to lesion resolution. Friis et al. assessed nickel release from guitar strings used by a guitar player allergic to nickel. The man manufactured electric guitars and also played the guitar in a professional band. Eczema was only located on the left hand, which was the only hand in contact with 
the strings when he played. He was tested with the European standard series and was positive to nickel sulphate, while the dimethylgloxime test on the three types of guitar string used (nickel-plated steel, pure nickel wound 150L and pure nickel wound 150S) was negative. Analysis for nickel release from the strings following the recommended EN 1811 standard method (one week of immersion in artificial sweat) showed nickel release below the detection limit of the atomic absorption spectrophotometer. A new test was performed with more aggressive artificial sweat $(\mathrm{pH} 4.8)$ and a higher content of sodium chloride and this time the wraps were separated from the other parts of the strings. Nickel release from 20 to $53 \mu \mathrm{g} / \mathrm{cm}^{2} / 3$ days was found and was higher than the limit fixed by the European regulation on nickel $\left(0.5 \mu \mathrm{g} / \mathrm{cm}^{2} /\right.$ week $)$.

Inoue et al. [20] reported an eczema on the chin and lips of a flautist, the location of the eczema matched the area in contact with the flute. She had been playing the flute for 6 years without any problem. The eruption on her chin appeared 2 months after she developed earlobe dermatitis from costume earrings. Patch testing showed a positive reaction to nickel in the European standard series. A dimethylglyoxime spot test on the flute was negative, however, spectrometry (ICPS) analysis showed the flute contained $0.067 \%$ nickel. Nakamura et al. reported erythema and wheals around the mouth and on the lips and eyelids of a trumpet player with positive patch tests to nickel. The patient also reported eczema when she had worn costume jewellery around her finger and neck. When plastic was applied on the mouthpiece of the trumpet and she avoided wearing costume jewellery she then had no further relapse. Vine and Deleo [21] reported a case of eczema on both forearms, on the upper arms and upper chest in a tuba player. Patch testing with the North-American standard series and a metal series showed sensitisation to several metals, nickel, palladium and cobalt. The tuba was made of brass but some parts (connectors and metal brackets) were positive to the dimethylglyoxime test. The use of topical corticosteroids and clothes to reduce skin contact with the metal parts releasing nickel led to great clinical improvement. The patient was advised to buy a silver tuba. Jacob and Herro described a vesicular hand dermatitis in a young boy which developed a few months after he started playing the trombone [22]. Patch testing confirmed a positive reaction to nickel and the dimethylglioxime test was highly positive on the parts where there was worn plating. Fisher reported a case of allergic cheilitis from a nickel-plated harmonica; the patient had a positive patch test reaction to nickel and the instrument showed strong reaction to the dimethylglyoxamine test [23].

\section{Chromium}

Buckley and Rogers [24] reported a case of dermatitis in a professional violinist. It started on the left ring finger and spread to both hands and feet. The left hand was more severely affected. Patch testing gave positive reactions to chromium and cobalt. Sources of chromium exposure in this patient were the leather violin case and the E-string. The E-string used by the patient was chromium-plated steel. Changing the violin case and the E-string to a standard type resulted in rapid clearing of the dermatitis.

Nethercott et al. [25] reported an eczematous eruption on the fingertips of the right hand in a female harpist. Patch testing gave a positive reaction to potassium dichromate. The patient used chromium salts as a tanning agent for the harp strings.

\section{Colophony}

Also called colophonium or rosin, colophony is a resin obtained from conifers. Its composition varies depending on the species of conifer, the geographic origin, the manufacturing process and the storage method. It contains about $90 \%$ of resin acids and $10 \%$ of neutral substances. Resin acids are diterpenic acids, mainly of two types: abietic acid (two conjugated double bonds) and pimaric acid (two non-conjugated double bonds) [26].

Colophony is used to better grip the strings. Powdered colophony is made of rough particles that modify the friction coefficient and allow the bow hair to grip the strings and make them vibrate (by pulling them and letting them go). In colophony, the allergens most often responsible for dermatitis are the oxidation products of abietic and dehydrobietic acids (hydroperoxides, peroxides, epoxides and ketones) [26]. Many cases of allergy to colophony have been reported in musicians, particularly in violinists and cellists [12, 27-31]. Eczema mainly involves the hands but also the neck and face [28]. The colophony used for violin strings can cause airborne dermatitis of the face as colophony particles are dispersed in the air. Thus, eye-lid contact dermatitis can be the sole clinical manifestation of colophony allergy in violinists [32].

Vandebuerie et al. recently reported ACD from multiple exposure to colophony in a double bassist. The lesions affected several parts of the body depending on what had caused them: the legs after she had waxed them, an eruption on the upper arm after contact with a wooden door, the face and the five fingers of the right hand in relation to double bass playing. Sources of exposure were colophony for the double bass strings and the depilating strips. Avoidance of all colophony sources resulted in rapid clearing of the dermatitis. As regard the double bass, the rosin was replaced with the hypoallergenic Super-Sensitive Claritiy ${ }^{\circledR}$ synthetic Rosin (Musical String Co, Sarasota, Fl, USA), as a result the patient remained free of dermatitis [27].

Alvarez and Branccio [29] reported a similar case in a violinist who was referred with a 6-month history of an eruption of the fingertips of her left hand, the hand in contact with the strings and fingerboard. Patch testing elicited a positive reaction to nickel, cobalt, colophony in the standard series, professional colophony, neomycin sulphate, formaldehyde and 3 formaldehyde-releasing preservatives (quaternium-15, imidazolidinyl urea and diazolidinyl urea) and to shavings from natural ebony (botanical name unspecified). Dimethylgloxime spot test was positive on the E-string. Avoiding allergens can prove difficult. She was advised to use Clarity ${ }^{\circledR}$ Rosin, a synthetic colophony. As for the nickel contained in the strings, there are pure gut strings but the quality of sound is different and often unacceptable at a professional level. Changing the ebony fingerboard to a different type of wood fingerboard can be more easily accomplished. Other cases of ACD from colophony have been reported in violinists and string instrumentalists [30]. Van Ketel and Bruynzeel [33] reported ACD in a man who repaired accordions. He had dermatitis on the face and hands related to his occupation. Patch testing showed positive reactions to colophony, balsam of Peru and the 
beeswax he used (containing colophony), tested at $20 \%$ in methyl ethyl ketone (MEK). Patch testing with pharmaceutical grade beeswax (20\% MEK), propolis and oil of turpentine $(0.3 \%)$ was negative. The mixture of beeswax and colophony was gently heated by the patient before use.

\section{Woods and plants}

Dermatitis from wood is uncommon in musicians; it is most often reported in musical instrument manufacturers who are in contact with raw wood and wood dust. The responsible allergens are mainly benzo-, naphto-, firanoand phenanthrene quinones, stilbenes, phenolic compounds and terpenes. Species of the genera Dalbergia and Marchaerium which are widely used because of their hardness, resistance to fungi and beauty, contain sensitising quinones, called dalbergiones, which are included in the group of neoflavonoids [34]. Each species of wood has a different profile of dalbergiones. The major allergen is (R)-3,4dimethoxydalbergione, it is the strongest sensitiser among the dalbergiones and is only found in Pao ferro or Santos rosewood (Machaerium scleroxylon Tul). Obtusaquinone and (R)-4-methoxydalbergione are the main sensitisers of Cocobolo (Dalbergia retusa Hemsl). Table 2 provides a list of sensitisers inducing allergic contact dermatitis from wood.

\section{Wind instruments}

Pföhler et al. reported a case of ACD of the lips in a recorder player who had played the flute for thirty years. He had had a two-year history of recurrent dermatitis of the lips. He used 5 different recorders made from African blackwood (Dalbergia melanoxylon), cedar, olive, rosewood and pear. Patch testing with the German standard series and sawdust from the five recorders ( $10 \%$ pet.) showed positive results

Table 2. Sensitisers in woods [35-38].

\begin{tabular}{|c|c|c|c|}
\hline Botanical name & English name & Sensitisers & $\begin{array}{l}\text { Patch test } \\
\text { concentration }(\%)\end{array}$ \\
\hline Acacia melanoxylon R. Br & $\begin{array}{l}\text { Australian blackwood, acacia } \\
\text { blackwood }\end{array}$ & $\begin{array}{l}\text { Melacidin } \\
\text { Acamelin }\end{array}$ & $\begin{array}{l}1 \\
1\end{array}$ \\
\hline Apuleia leiocarpa & Garapa & Oxiayanin A and B & 1 (each) \\
\hline Bowdichia nitida Bentham. & Sucupira & $\begin{array}{l}\text { 2,6-dimethoxybenzoquinone } \\
\text { Bowdichione }\end{array}$ & $0.1 \%$ \\
\hline Brya ebenus (L.) DC & Cocus wood & $\begin{array}{l}\text { 7,8-dihydroxy-2',4',5'- } \\
\text { trimethoxyisoflavone }\end{array}$ & 1 \\
\hline $\begin{array}{l}\text { Chlorofora excelsa Benth \& } \\
\text { Hook }\end{array}$ & African Teak, Iroko & Chlorophorin & 10 \\
\hline $\begin{array}{l}\text { Cordia decandra } \\
\text { Cordia goeldiana }\end{array}$ & $\begin{array}{l}\text { Ziricote } \\
\text { Freijo }\end{array}$ & $\begin{array}{l}\text { Cordiachromes } \\
\text { Cordiachromes }\end{array}$ & $\begin{array}{l}0.1 \% \\
0.1\end{array}$ \\
\hline Dalbergia nigra Fr. All & $\begin{array}{l}\text { Brazilian rosewood, Bahia } \\
\text { rosewood, jacaranda }\end{array}$ & $\begin{array}{l}\text { Obtusaquinone, } \\
\text { (R)-4-methoxydalbergione }\end{array}$ & 1 \\
\hline Dalbergia retusa Hemsl & Cocobolo & $\begin{array}{l}\text { Obtusaquinone, } \\
\text { (R)-4-methoxydalbergione }\end{array}$ & 1 \\
\hline Dalbergia latifolia Roxb. & $\begin{array}{l}\text { East Indian rosewood, Indian } \\
\text { rosewood }\end{array}$ & dalbergiones & 1 \\
\hline $\begin{array}{l}\text { Dalbergia melanoxylon Guill. } \\
\& \text { Perr. }\end{array}$ & African blackwood & dalbergiones & 1 \\
\hline $\begin{array}{l}\text { Diospyros crassiflora Hiern. } \\
\text { Diospyros celebica Bakh. } \\
\text { Diospyros ebenum Koenig }\end{array}$ & $\begin{array}{l}\text { African ebony } \\
\text { Macassar ebony } \\
\text { Ceylon ebony, East indian } \\
\text { ebony }\end{array}$ & Macassar quinone & 1 \\
\hline $\begin{array}{l}\text { Distemonanthus benthamianus } \\
\text { Baill }\end{array}$ & Ayan, Movingui & Oxiayanin A and B & 1 (each) \\
\hline Grevillea robusta A. Cunn & Southern silky oak & Grevillol & 0.1 \\
\hline Khaya anthotheca C. DC & $\begin{array}{l}\text { African mahogany, white } \\
\text { mahogany }\end{array}$ & Anthothecol & 1 \\
\hline Machaerium Scleroxylon Tul. & $\begin{array}{l}\text { Pau ferro or pao ferro, Morado, } \\
\text { Bolivian Rosewood, Santos } \\
\text { Rosewood }\end{array}$ & (R)-3,4-dimethoxy-dalbergione & 0.01 \\
\hline Mansonia altissima A. Chev. & Mansonia & Mansonone A & 0.1 \\
\hline Paracetoma peroba Kuhlm & Peroba, white peroba, & Lapachenol & 1 \\
\hline Swietenia mahogany & West Indies Mahogany & $\begin{array}{l}\text { Anthothecol, 2,6- } \\
\text { dimethoxybenzoquinone }\end{array}$ & 1 \\
\hline Tabeuia spp. & Roble & Lapachol, lapachone & 1 \\
\hline Tectona grandis L. & Teak & Deoxylapachol & 0.01 \\
\hline Thespesia populnea (L) Sol & Portia tree & Mansonone X & 3 \\
\hline Thuja plicata D. Don & Western red cedar & Thymoquinone & 0.1 \\
\hline
\end{tabular}


for FM II, Lyral, African blackwood and rosewood. There was no mention of the botanical name of the rosewood. Another similar case is reported in a recorder player by Van Neer et al. [39]. He had hyperkeratotic eczema with painful fissures of the fingertips. Symptoms were aggravated each time he played his recorder. He used 3 different recorders made from boxwood (Buxus sempervirens), cedar and rosewood (unspecified botanical name). Patch testing with the sawdust from the different recorders gave positive results for boxwood only. Discontinuation of playing his boxwood recorder led to complete resolution of symptoms in the patient. He had never had cheilitis because the mouthpiece was made of cedar wood.

Rojas-Hijazo reported 7 cases of ACD from Cocobolo, also called Nicaraguan rosewood or palisander, a South American wood used by gaïta (bagpipes) constructors [40]. Wong et al. reported a case of ACD from Pao ferro (Machaerium scleroxylon) in a bagpipes maker [41].

Several cases of contact allergy to cane reeds (Arundo donax) of wind instruments have been reported [42-45]. The reed is a thin strip made from the bark of Arundi donax. Mariano et al. [42] reported a case in a saxophonist referred to them for patch erythema, desquamation, hyperkeratosis and peripheric vesiculation of the median area of the lower lip. The symptoms developed 2 months after he replaced a plastic reed with a cane reed. Patch testing with fragments of the cane reed gave positive results (++) in the patient whereas the results were negative in 10 volunteers. Switching back to a plastic reed led to full recovery. McFadden $e t$ al. [43] reported a similar case in a young female clarinettist who had erythematous and squamous lesions on the median area of the lower lip. Patch testing also gave positive results for the scrapings of the Arundo donax cane reed. Substitution of the cane reed with a plastic-coated reed led to rapid clearing of her condition.

\section{String instruments}

Several cases of ACD from wood have been reported in guitar manufacturers. No case has been reported in guitar players. Bonny et al. [34] reported a severe case of ACD caused by Pao ferro or santos rosewood (Machaerium scleroxylon Tul.) in a guitar maker. He had dermatitis of the hands, arms, face, chest and genitals. Patch testing gave positive results for black walnut and santos rosewood dust (10\% pet.). Avoidance of contact with these woods, together with the use of East Indian rosewood, instead led to recovery. Shimizu et al. [46] reported a case of erythema multiforme in a female luthier who made guitars. She had an eruption with target lesions with blisters and a positive Nikolsky sign on the trunk, arms and ankles. Oral and genital lesions were absent. In the 7 days preceding the eruption, the patient had handled Pao ferro and two types of mahogany wood. Patch testing gave positive results for Pao ferro. Five months later, when the patient accidentally touched Pao ferro again, she developed similar lesions on her hands. Pao ferro (M. sceroxylon) is particularly used to make guitars. A case of ACD to padauk wood (Pterocarpus dalbergioides) and purpleheart (Peltogyne leuminosae) has been reported in a guitar-maker [47].

Kuner and Jappe reported a case of ACD from ebony, colophony and turpentine in a female violinist. Clinical examination showed eczematous and erosive lesions in the area where the violin touched the neck, jaw and shoulder.
Patch testing gave positive reactions to colophony, turpentine, formaldehyde, ebony and the lacquer of the violin. The concentrations, the botanical name of the ebony involved and the composition of the lacquer were not mentioned.

The woods of chinrests were responsible for some cases of allergic contact dermatitis of the neck: ebony wood (Diospyros sp.), Indian rosewood (Dalbergia latifolia Roxb.) and Brazilian rosewood (Dalbergia nigra All.) [4850]. Lately, Lazzarini et al. reported a case of ACD to Pao ferro in an amateur viola player who had a fiddler's neck [51]. The replacement of the wooden chin rest by a silicon one improved his condition and enabled him to carry on playing the viola.

\section{Organ}

Jemec and Murphy [52] reported a case of contact dermatitis in an organist 3 months after a new organ was installed. She developed an eruption on the fingertips, eyelids and face. Patch testing with wood scrapings in ethanol (24 hours) as is and at various dilutions in petrolatum (10\%, $1 \%, 0.1 \%, 0.01 \%$ ) gave positive results for the wood of the organ keyboard. The wooden keyboard was unvarnished and untreated. The wood was identified as Brazilian boxwood (a species of Aspidosperma). After the keyboard was replaced, all her symptoms disappeared. Eastlander reported another case in an organ maker [53]. The causative wood was western red cedar (Thuja plicata D. Don).

\section{Propolis}

Propolis [54] is the resinous substance that bees collect from plants, mainly from poplar buds in Europe, mixed to bee saliva and beeswax. It has several functions and is used to repair and strengthen honeycombs and ensures the hive is waterproof. The composition of propolis varies depending on its geographical origin. Propolis from temperate regions contains mostly phenolic substances, flavonoid aglycones, aromatic acids and their esters. The main allergens are caffeic acid esters such as 3-methyl-2-butenyl caffeate, benzyl caffeate, phenylethyl caffeate and geranyl caffeate. Anecdotal cases of occupational ACD from varnished wood have been reported.

Lieberman et al. reported the case of a violin maker who developed ACD to propolis, a component of an Italian varnish [55]. Another case was published in Medicine des Arts by Arcier [56] in a luthier who repaired period string instruments and was also an amateur violinist. He developed eczema on the left ear, the face, hands and forearms. Patch testing gave positive results for the colophony and propolis contained in an Italian varnish.

\section{Dyes}

Bork [48] reported a case of fiddler's neck syndrome that developed in a professional violinist a few weeks after the use of a new chin rest made of ebony wood. Patch testing gave positive results for $\mathrm{p}$-phenylenediamine (PPD) and toluene-2,5-diamine, 2 dyes, and negative results for ebony wood, Indian rosewood (Dalbergia latifolia Roxb.) and Brazilian rosewood (Dalbergia nigra All.). As the chin rest made of ebony wood was not considered sufficiently black, it was coloured with a stain containing p-phenylenediamine. Changing the chin rest to one made of boxwood (Buxus sempervirens L.) resulted in rapid healing. O'Hagan et al. reported a case of ACD in a young amateur cellist. She had 
lesions on the first three fingers of her right hand in contact with the bow. Patch testing gave positive results for PPD. The manufacturer of the bow confirmed that PPD had been used to stain it [57].

\section{Rubber}

Herro et al. [58] reported a case of thumb dermatitis in a young violinist. The thumb was in contact with the rubber part of the bow. Patch testing gave a positive reaction to carbamix. His condition improved after he covered the rubber part of the violin bow with surgical tape.

Hallai et al. [59] reported a case of cheilitis and wheals in a young amateur musician during periods of rehearsals when playing the trumpet. Patch testing showed positive reactions to thiuram mix, N-isopropyl-N'-phenylenediamine (IPPD), PPD (history of black henna tattoo) and to the rubber foam linings of his instrument cases.

\section{Urticaria}

Ruiz-Hornillos et al. [44] reported a case of oropharingeal itching and edematous swelling of the lower lip in a young clarinettist with a history of pollinic rhinoconjunctivitis and oral allergy syndrome to peach, pear, apple, orange, almond and nut. The swelling of the lower lip (in contact with the cane reed) occurred minutes after she started playing the clarinet. Prick-to-prick test with the cane reed (Arundo donax) was positive $(4 \times 7 \mathrm{~mm})$. Serum specific IgE (ELISA) to major allergens of Poaceae pollen Ph1 p 1 and $\mathrm{Ph} 1 \mathrm{p} 5$ measured 6.73 and $12.78 \mathrm{kU} / \mathrm{l}$, respectively, and $15.1 \mathrm{kU} / \mathrm{L}$ to profilin. Immunoblotting found a $35 \mathrm{kDA}$ protein for a cane reed extracts. It could easily correspond to the major grass group I allergens (27-35 kDa). These allergens belong to the beta-expansin family, glycoproteins expressed in most pollen allergies.

Patruno et al. [60] reported a case of vibratory angioedema in a professional saxophonist. The patient had a six-month history of recurrent lower lip swelling which appeared a few minutes after he started playing the saxophone and persisted for about 60 minutes. Patch testing with fragments of the cane reed of the saxophone gave negative results at 20 minutes, 48 hours and 72 hours. Tests for physical urticaria (pressure, contact with cold and heat, dermographism and exercise) also yielded negative results. A laboratory vortex was then applied on the forearm and angioedema appeared after 5 minutes. The challenge test, i.e. inviting the patient to play the saxophone, caused oedema of the lower lip about 5 minutes after he started to play and persisted for 30 minutes. The patient experienced good control of the disease with lose-dose corticosteroid therapy 1 hour before playing.

\section{Other skin diseases}

Hyperhidrosis can have a negative impact on music performance but also corrodes the instrument and thus damages it. Some musicians need to have their instruments re-lacquered due to corrosion [7] [Jacques Rioux, a brass instrument repairer, personal communication].

Barkvoll et al. [61] found that, over an 8-month period, the incidence of herpes labialis in a group of 45 brass and woodwind military players was twice that of a control group of drummers and non-musician soldiers. Herpes labialis is a severe hindrance to musicians.

\section{Treatment - Preventive measures}

Proper performance technique helps reduce muscular tension and prevents injuries. To prevent the fiddler's neck syndrome, it is important to improve posture to reduce the friction between the skin and the instrument and, if necessary, to interpose a cloth between the neck and the chinrest [8].

\section{ACD}

In case of $\mathrm{ACD}$, the main measure is avoidance of the allergens but it is not always easy to implement regarding the high performance requirements in professional musicians. For instance, let us mention a few possible alternatives.

\section{Nickel}

Caero et al. [9] reported the case of a young violinist who developed ACD to the metal brackets of her violin. Her condition improved with the replacement of the chin rest by a hypoallergenic Wittner composite 4/4 side mount chin rest.

http://www.amazon.com/Wittner-Composite-ViolinChinrest-Hypoallergenic/dp/B0009SXWLC).

In case of dermatitis from nickel contained in brass instrument mouthpieces, it is possible to replace them by plastic or gold-plated mouthpieces [5, 12].

\section{Wood}

In case of cane reed allergy, synthetic reeds are available. However, the sound quality is not the same.

\section{Colophony}

Vandebuerie et al. reported allergic contact dermatitis from colophony in a double bassist. The replacement of natural colophony with the hypoallergenic Super-Sensitive Claritiy ${ }^{\circledR}$ synthetic Rosin (Musical String Co, Sarasota, Fl, USA) resulted in rapid clearing of the dermatitis [27]. However, it seems that the sound quality is not quite the same, particularly as regards violinists.

\section{Infections}

Herpes labialis is a severe hindrance and alters musical performance, thus prophylactic acyclovir treatment during the concert season can prove useful for brass and wind instrumentalists with recurrent herpes labialis [7].

\section{Conclusion}

Skin diseases in professional musicians can have serious consequences on the quality of the musical performance and on the careers of professional musicians. The key preventive measures are early management of the skin disease and specific tests depending on the symptoms, which will lead to the replacement and avoidance of the causative allergens, together with better knowledge of proper performance techniques and postures to reduce trauma. 


\section{Special thanks}

The author wishes to thank the following people for their help and advice: Dr Nabi Belrhomari (occupational physician at la Bourse medical centre), Dr Iris Brémaud (research fellow at CNRS (Equipe BOIS) and LMGC (Mechanical and Civil engineering Laboratory) of Montpellier University), Alain Hérou (bow-maker in Paris), Emmanuelle Faillat (luthier in Paris), Michael Jousserand (Research and Development engineer at Buffet-Group) and David Zambon (director of the Marcel Dupré conservatory of music in Meudon).

Disclosure. Acknowledgments: The GERDA thanks Basilea, Pierre Fabre and Unilever for their institutional support for publication of this article. Financial support: none. Conflict of interest: none.

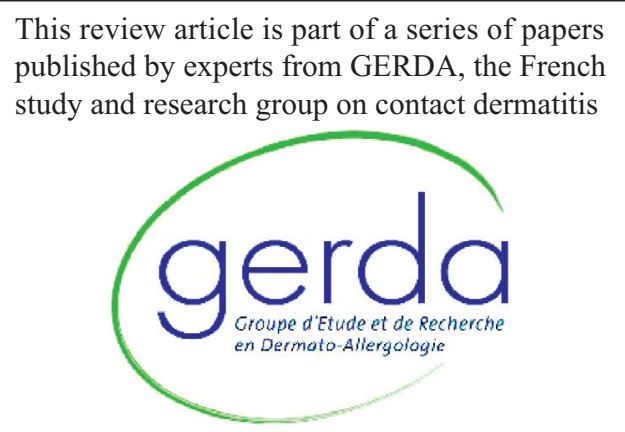

\section{References}

1. Baccouche D, Mokni M, Ben Abdelaziz A, Ben Osman-Dhahri A. [Dermatological problems of musicians: a prospective study in musical students]. Ann Dermatol Vénéréol 2007; 134: 445-9.

2. Classification des instruments de musique. Médecine des Arts. available at: http://www.medecine-des-arts.com/Classification-desinstruments-de.htmledecoupe_recherche=classification $\% 20 \mathrm{des} \% 20$ instruments (accessed 28 Jan 2015).

3. Bremaud I. Diversité des bois utilisés ou utilisables en facture $\mathrm{d}$ 'instruments de musique. Thèse de doctorat. Université Montpellier II Sciences et Techniques du Languedoc. 2006.

4. Gambichler T, Uzun A, Boms S, Altmeyer P, Altenmüller E. Skin conditions in instrumental musicians: a self-reported survey. Contact Dermatitis 2008; 58: 217-22.

5. Onder $M$, Aksakal AB, Oztaș $M O$, Gürer MA. Skin problems of musicians. Int J Dermatol 1999; 38: 192-5.

6. Piraccini BM, Antonucci $A$, lorizzo $M$, Pazzaglia $M$, Tosti $A$. Occupational nail fragility in a professional violist. Contact Dermatitis 2004; $51: 35-6$

7. Rimmer S, Spielvogel RL. Dermatologic problems of musicians. J Am Acad Dermatol 1990; 22: 657-63.

8. Knierim C, Goertz W, Reifenberger J, Homey B, Meller S. [Fiddler's neck]. Hautarzt Z Für Dermatol Venerol Verwandte Geb 2013; 64:724-6.

9. Caero JE, Cohen PR. Fiddler's neck: Chin rest-associated irritant contact dermatitis and allergic contact dermatitis in a violin player. Dermatol Online J 2012; 18: 10.
10. Tennstedt $D$, Cromphaut $P$, Dooms-Goossens A, Lachapelle JM. Dermatoses of the neck affecting violin and viola players («fiddler's neck», and contact dermatitis). Dermatosen Beruf Umw Occup Environ 1979; 27: 165-9.

1 1. Lachapelle JM, Tennstedt $D$, Cromphaut P. Pseudofolliculitis of the beard and «fiddler's neck». Contact Dermatitis 1984; 10: 247.

12. Gambichler $T$, Boms $S$, Freitag $M$. Contact dermatitis and other skin conditions in instrumental musicians. BMC Dermatol 2004; 4:3.

13. Crépy $M N$. Dermatoses professionnelles allergiques aux métaux : allergie de contact au nickel. Fiche d'allergologie-dermatologie professionnelle TA 84. Doc Méd Trav 2010; 121:91-104.

14. Jue MS, Kim YS, Ro YS. Fiddler's Neck Accompanied by Allergic Contact Dermatitis to Nickel in a Viola Player. Ann Dermatol 2010; 22: 88-90.

15. Pincelli C, Motolese A, Pincelli L. Fiddler's neck and nickel dermatitis. Contact Dermatitis 1985; 13:37.

16. Machácková J, Pock L. Occupational nickel dermatitis in a cellist. Contact Dermatitis 1986; 15:41-2.

17. Marshman G, Kennedy CT. Guitar-string dermatitis. Contact Dermatitis 1992;26: 134

18. Smith VH, Charles-Holmes $R$, Bedlow A. Contact dermatitis in guitar players. Clin Exp Dermatol 2006; 31: 143-5.

19. Friis UF, Menné T, Jellesen MS, et al. Allergic nickel dermatitis caused by playing the guitar: case report and assessment of nickel release from guitar strings. Contact Dermatitis 2012;67: 101-3.

20. Inoue $A$, Shoji $A$, Fujita T. Flautist's chin. $\mathrm{Br} J$ Dermatol 1997; 136: 147.

21. Vine K, Deleo V. Dermatologic manifestations of musicians: a case report and review of skin conditions in musicians. Cutis 2011;87: 117-21.

22. Jacob SE, Herro EM. School-issued musical instruments: a significant source of nickel exposure. Dermat Contact Atopic Occup Drug 2010; 21:332-3.

23. Fisher AA. Allergic contact dermatitis from musical instruments. Cutis 1993; 51:75-6.

24. Buckley DA, Rogers $S$. «Fiddler »s fingers': violin-string dermatitis. Contact Dermatitis 1995; 32: 46-7.

25. Nethercott JR, Holness DL. Dermatologic problems of musicians. J Am Acad Dermatol 1991; 25: 870.

26. Crépy $M N$. Dermatoses professionnelles à la colophane. Fiche d'allergologie-dermatologie professionnelle TA 65. Doc Méd Trav 2002; 89: 75-82.

27. Vandebuerie L, Aerts C, Goossens A. Allergic contact dermatitis resulting from multiple colophonium-related allergen sources: multiple colophonium-related allergen sources. Contact Dermatitis 2014;70: $117-9$.

28. Kuner $N$, Jappe $U$. Allergic contact dermatitis from colophonium, turpentine and ebony in a violinist presenting as fiddler's neck. Contact Dermatitis 2004; 50: 258-9.

29. Alvarez MS, Brancaccio RR. Multiple contact allergens in a violinist. Contact Dermatitis 2003; 49: 43-4.

30. Murphy J, Clark C, Kenicer K, Green C. Allergic contact dermatitis from colophony and Compositae in a violinist. Contact Dermatitis 1999; 40: 334.

31. Angelini G, Vena GA. Allergic contact dermatitis to colophony in a violoncellist. Contact Dermatitis 1986; 15: 108.

32. Brasileiro A, Campos $S$, Cabete J, Diamantino F, Lobo L. Look into the music : a case of eyelid contact dermatitis in a violonist. Contact Dermatitis 2014;70: 100.

33. Van Ketel WG, Bruynzeel DP. Occupational dermatitis in an accordion repairer. Contact Dermatitis 1992; 27: 186.

34. Bonny $M$, Aerts $O$, Lambert J, Lambert J, Lapeere H. Occupational contact allergy caused by pao ferro (santos rosewood): a report of two cases. Contact Dermatitis 2013; 68: 126-8.

35. Crépy $M N$. Dermatoses professionnelles aux végétaux. Fiche d'allergologie-dermatologie professionnelle TA 73. Doc Méd Trav 2006; 105: 77-90.

36. De Souza A, Cohen D. Contact Dermatitis in Cabinet Makers. In: Rustemeyer T, Elsner P, John SM, Maibach HI, eds. Kanerva's Occu- 
pational Dermatology. $2^{\text {nd }}$ edn. Springer Publications, 2012: 130. $1319-26$.

37. Cook DK, Freeman S. Allergic contact dermatitis to multiple sawdust allergens. Australas J Dermatol 1997; 38: 77-9.

38. Hausen BM. Woods. In: Rustemeyer T, Elsner P, John SM, Maibach $\mathrm{HI}$,eds. Kanerva's Occupational Dermatology. $2^{\text {nd }}$ edn. Springer Publications, 2012: 73. 825-37.

39. Neer FJMA, Ginkel CJW. Allergic contact dermatitis form a boxwood recorder. Contact Dermatitis 1997; 36: 305

40. Rojas-Hijazo B, Lezaun A, Hausen BM, Segura N, Garcés $M$, Colás $C$. Airborne contact dermatitis in gaitas (flageolets) constructors after exposure to sawdust of caviuna. Contact Dermatitis 2007; 56: 274-7.

41. Wong YW, Powell SM. Contact dermatitis in a bagpipes maker. Contact Dermatitis 2003; 49:310.

42. Mariano $M$, Patruno $C$, Lembo $S$, Balato $N$. Contact cheilitis in a saxophonist. Dermat Contact Atopic Occup Drug 2010; 21 : 119-20.

43. McFadden JP, Ingram M, Rycroft RJ. Contact allergy to cane reed in a clarinettist. Contact Dermatitis 1992; 27: 117.

44. Ruiz-Hornillos FJ, Alonso E, Zapatero L, Pérez C, Martínez-Molero I. Clarinetist's cheilitis caused by immediate-type allergy to cane reed. Contact Dermatitis 2007; 56: 243-5.

45. Petrus $M$, Houbart $N$, Dornon $X$. Allergie à Arundo donax. Une nouvelle observation chez un jeune clarinettiste. Rev Fr Allergol 2009; 49: 25-7.

46. Shimizu S, Chen KR, Pratchyapruit WO, Shimizu H. Tropicalwood-induced bullous erythema multiforme. Dermatol Basel Switz 2000; 200: 59-62.

47. Mehta AJ, Statham BN. Allergic contact dermatitis to purpleheart and padauk wood (Pterocarpus dalbergiodes). Contact Dermatitis 2007; 56: 245.

48. Bork K. Allergic contact dermatitis on a violinist's neck from para-phenylenediamine in a chin rest stain. Contact Dermatitis 1993; 28: 250-1.
49. Hausen BM. Chin rest allergy in a violinist. Contact Dermatitis $1985 ; 12: 178-80$

50. Haustein UF. Violin chin rest eczema due to east-indian rosewood (Dalbergia latifolia ROXB). Contact Dermatitis 1982; 8: 77-8.

51. Lazzarini $R$, De Figueiredo Silva $M$, Duarte I. Contact dermatitis to pao ferro wood in a viola player. Contact Dermatitis 2014;70: 104.

52. Jemec GB, Hausen BM. Contact dermatitis from Brazilian box tree wood (Aspidosperma sp.). Contact Dermatitis 1991;25: $58-60$.

53. Estlander T, Jolanki R, Alanko K, Kanerva L. Occupational allergic contact dermatitis caused by wood dusts. Contact Dermatitis 2001; 44: $213-7$.

54. De Groot AC. Propolis: a review of properties, applications, chemical composition, contact allergy, and other adverse effects. Dermat Contact Atopic Occup Drug 2013; 24: 263-82.

55. Lieberman HD, Fogelman JP, Ramsay DL, Cohen DE. Allergic contact dermatitis to propolis in a violin maker. J Am Acad Dermatol 2002; 46: S30-31.

56. Arcier F. Allergie cutanée chez un violoniste et un luthier. Médecine des Arts. 2010 available at : http://www. medecine-des-arts.com/Allergie-cutanee-chez-un.html. (accessed 28 jan 2015).

57. O'Hagan $A H$, Bingham EA. Cellist's finger dermatitis. Contact Dermatitis 2001;45:319.

58. Herro EM, Friedlander SF, Jacob SE. Violin bow-associated rubber allergy in a child. Dermat Contact Atopic Occup Drug $2011 ; 22: 223-4$

59. Hallai N, Meirion Hughes T, Stone N. Contact allergy to thiuram in a musician. Contact Dermatitis 2004; 51: 154.

60. Patruno C, Ayala F, Cimmino G, Mordente I, Balato N. Vibratory angioedema in a saxophonist. Dermat Contact Atopic Occup Drug 2009; 20: 346-7.

61. Barkvoll $P$, Attramadal A. Recurrent herpes labialis in a military brass band. Scand J Dent Res 1987; 95: 256-8. 